\title{
Teachers' Sense of Community in Rural Learning Ecologies
}

\author{
Dipane Hlalele \\ ORCID iD: https://orcid.org/0000-0003-4455-4876
}

\author{
Moeketsi Mosia \\ ORCID iD: https://orcid.org/0000-0002-7189-0018
}

\begin{abstract}
This paper reports on the findings of a baseline study that sought to explore teachers' sense of community in so far as it contributes to sustainable rural learning ecologies. Community is a group of people who, together, share the feeling they belong to something, can influence and be influenced by one another, and can have their needs fulfilled by fulfilling the needs of the group. This small-scale mixed-method (quantitative and qualitative) study administered the revised 24-item Sense of Community Index (SCI-2) questionnaire on 161 male and female teachers randomly selected from rural schools in the eastern Free State region of South Africa. The questionnaire was tested for reliability using the Cronbach alpha coefficient and was found to have a reliability score of 0.71 , indicating an acceptable reliability coefficient. In addition, three narratives from teachers in one rural school were sourced. Findings indicated that teachers who stay in urban areas but are employed in rural schools evinced similar sense of belonging, membership, shared emotional connection as well as influence as their counterparts who stay in rural learning ecologies.
\end{abstract}

Keywords: Cronbach alpha; membership; questionnaire; Rural schools; shared emotional connection 


\section{Introduction}

Teacher shortages in rural South Africa are common. Phakathi (2013) states that in an attempt to curb the shortage, the Department of Basic Education (DBE) is considering making it compulsory for new teacher graduates to at least have been engaged in teaching in rural schools as part of their training. The decision to demand that student teachers serve in rural areas before they complete has been practiced elsewhere in the country. Some South African universities including University of Kwazulu Natal, Nelson Mandela Metropolitan University as well as the University of the Free State have embarked on concerted efforts to introduce student teachers to schools in rural learning ecologies with the expectation that such students will be more likely to accept teaching posts in these ecologies. As expected, placing student teachers in rural schools yielded some desirable results where the students indicated that the exposure made them appreciate rural areas more and 'gain a competitive advantage' (Hopkins, Raymond \& Carlson 2011:337) in the process. The DBE (cited in Phakathi 2013) reports that 6641 schools in South Africa had fewer than six teachers and more than 20000 teachers were obliged to teach multigrade classes. A great majority of children in rural poor communities continue to receive less than is their right in a democratic South Africa. Worse still is a fact that this will have long-term effects on their opportunities for development, their capabilities and their lives. Moreover, the communities in which they live will continue to suffer the debilitating effects of poverty and inequality for as long as these problems remain (Nelson Mandela Foundation 2005:viii-ix). A case for rural education can be advanced on the following grounds (Nelson Mandela Foundation 2005:139):

- Urban constituencies are more organized and vocal than rural ones and have succeeded substantially in monopolizing attention.

- The universal framework employed in government and policy documents is insufficiently sensitive to the specific conditions and needs of the rural poor.

- Education cannot compensate for poverty and inequality, and social inequalities need to be addressed before rural education will change.

According to Barley (2009:10) rural schools continue to experience difficulty recruiting and retaining new and qualified teachers. The teachers recruited for 
rural schools must be prepared for the conditions of rural teaching. They not only must have the credentials they need, but they should also be aware of the nature of rural schools and communities. Furthermore, teachers in rural learning ecologies need to be acutely aware of the increasing diversity in rural schools and communities (Wenger, Dinsmore \& Villagomez 2012:1). The importance of teacher preparation for rural learning ecologies cannot be over emphasised. In focusing on the role of teacher education, White and Reid (2008, as cited in Cline, White \& Lock 2013:1) also identified links between the sustainability of rural communities and teacher preparation, finding that rural communities stand to benefit from teacher education that is inclusive of rural education needs. White (2010) further argued that the relationships between rural schools and local communities need to be reciprocal, whereby successes in the areas of rural leadership and community collaboration can inform teacher education practice.

It has further been noted that rural learning ecologies are not well known and appreciated. Historically, rurality and rural education have been marginalised bodies of knowledge in South Africa and little is known of the focus of the various studies and the state of rural education and rural education research (Nkambule, Balfour, Pillay \& Moletsane 2011:341). Over and above what Nkambule et al. (2011) suggest, i.e., little is known about rural research, the little knowledge that authorities have seem to take a long time to be acted upon. One of the problem areas in rural education is multigrade teaching. A study by the Centre for Education Policy Development (CEPD), probed the teaching literacy and numeracy in multigrade classes in rural and farm schools in South Africa. This research analysed data as well as carrying out six case studies, in the North West province, using interviews with principals, interviews with teachers. Most of the schools that had these classes were poorly resourced. There was no curriculum adaptation, and the planning requirements were the same as those of the monograde classes. Teachers' exposure to suitable teaching strategies was limited, there was no specific teacher training on multigrade teaching, and no specific support was offered to these teachers. The learning materials were not always available in the mother tongue, and were not suitable for self-study. The continued neglect of the multigrade problems contributed to ongoing marginalisation of the poor, for whom multigrade schools were a reality (CEPD 2011).

Recruiting and retaining highly effective teachers (growing-your-owntimber!) may be a solution in many rural learning ecologies. Successful rural 


\section{Dipane Hlalele \& Moeketsi Mosia}

high schools are able to ensure an adequate number of high-quality teachers to boost academic success. Unfortunately, too many rural communities struggle to find and keep effective teachers. Even though rural teachers generally report a higher level of job satisfaction than their urban and suburban counterparts, rural communities have a higher number of less-qualified teachers and often lose their most experienced employees to higher-paying posts in nearby suburban and urban areas. Despite these ongoing challenges, an increasing number of rural communities are addressing these difficulties head-on with advanced technologies and distance learning that allow teachers to expand their professional development opportunities, as well as 'grow-your-own-timber' programs that encourage talented young people to stay and teach in their home communities (Hlalele 2012; 2014).

Mulkeen (2005) states that while the problem of teachers is usually linked to low numbers of teachers being produced by the system, in actual fact, there are qualified teachers in urban areas who are unemployed. Therefore, the existing shortage of teachers in rural learning ecologies may not be exclusively accounted for by general and current teacher shortage discourses. Mulkeen (2005) further alludes to the fact that teachers prefer to teach in urban areas while rural posts remain unfilled or when filled, the teachers who take on these posts tend to be unqualified and inexperienced. Therefore, there is a need to ensure that well trained and motivated teachers are made available for rural learning ecologies. In our view, incentives may contribute to attract teachers to rural learning ecologies. Teachers' sense of community constitutes one of the strongest aspect of recruiting, attracting and retaining teachers. According to Bennell (2004) and SACE (2011) local teachers are less likely to choose to migrate to urban areas if they have some ties to their local community. This means that if teacher training institutions were present within rural learning ecologies, those who attend them would be more likely to remain in their local areas and provide much needed teaching to these areas, willingly. Due to their ties with rural areas, their sense of community and attachment is likely to be greater. The purpose of the study is to explore the teachers' sense of community in rural learning ecologies.

Building viable models of community support and partnerships may also contribute to maximising efforts in rural ecologies. According to schools are also an important resource for connecting rural people to their community and promoting rural lifestyles (Hedlund 1993; Ferris, Oosterhoff \& Metzger 2013:2). Similar to churches, schools are often considered stable institutions 
within rural communities, providing rural residents with a sense of identity (Miller 1993; Ferris, Oosterhoff \& Metzger 2013:2). Schools not only provide the physical location for organized activities, but many school clubs build on academic curriculum outside the traditional school day. Rural communities play a vital role in the success or failure of their local schools. High-performing schools tend to depend on local community-based services, businesses, and other non-academic partners to stretch limited resources and support a common vision for change. Rural schools often have the benefit of small, tight-knit communities to help guide school improvement efforts and participate regularly in school activities. Unprecedented and widespread reliance on technology may also allow rural schools to engage local stakeholders in educational goals and outcomes more broadly than ever (Myende \& Hlalele 2018). Unfortunately, some rural ecologies may still lack the tax base, stable local economy, and sufficient social and community capital to invest adequately in sustainable endeavours. In areas that have lost a large number of young people and highly educated professionals to better paying jobs in nearby cities, retaining broadbased community support is also an ongoing challenge (Hlalele 2014).

Regarding migration from rural to urban areas, Cross, Seager, Wentzel, Mafukidze, Hoosen and Van Zyl (2009) and the South African Council for Educators (SACE) (2011:15), estimate that approximately half of all rural districts in South Africa undergo a net loss of population due to ruralto-urban migration. Young adult males in particular, with secondary education, are migrating out of rural areas in search of employment in urban areas.

Mulkeen (2005) identified three distinct challenges affecting teachers and accounting to why educational provision in rural learning ecologies may be described as weaker. They include: Teacher deployment practices which leave fewer teachers, more unfilled posts, and more unqualified teachers, in rural areas. Secondly, teacher utilization practices which result in larger class sizes at early grades, cases teachers without adequate preparation and materials are left trying to handle multigrade teaching. At the same time, qualified teachers may be found working with very small classes. Thirdly, there are limited teacher management systems which are likely to result in higher absenteeism, and shorter working hours, in rural areas. In addition the systems to ensure and develop the quality of teaching (inspection and support services) are often weaker in rural areas. In effect, the weakest teachers receive the least support. In addition, rural learning ecologies are often left with teachers who are described as desperate for jobs and who have failed to acquire jobs in other 
preferred areas (Wentzel \& Tlabela 2006; SACE 2011). The next section attempts to conceptualise the concept, sense of community.

\section{Sense of Community Conceptualised}

According to Brown and Schaff (2011:35) a community refers to a group of people organised around certain commonly held interests and attributes that help create a sense of shared identity. It implies a web of affective relationships that are qualitatively different from those constituting other kinds of human groups (Hlalele, Manicom, Preece \& Tsotetsi 2015; Hlalele \& Tsotetsi 2015; 2016). Being part of a community further implies long-term, continuous social interaction that contributes to the formation of personal, and to social and economic production and reproduction (Boyd \& Nowell 2017). As a result, members share a sense of belonging, of 'we-ness.' Mothowamodimo (2011: 23) draws from a few authors' opinions and views a sense of community as,

sets of people who may identify themselves with a place in terms of notions of commonality, shared values or solidarity in particular contexts. These values could be informed by the spirit of botho which is itself a community value. Other values include among others service, charity, respect, togetherness, and hospitality.

Jenny Fremlin, a community Psychologist, collated different theorists' views and describes the four factors that work in tandem with each other to create a sense of community. For each of the factors, he compiled descriptive keywords and phrases as follows (Fremlin 2012: 31; Vanover 2014: 17-20):

Membership: a sense of belonging, personal relatedness, investment of the self, feeling the right to belong, being part of the community, boundaries including identifying people who and people who do not belong, emotional safety (through belonging), feelings of acceptance, willingness to sacrifice for the group, identification with the group, sharing common symbols, and personal investment.

Influence: mattering, individual members making a difference to the group and the group having an influence on its members, conformity, members having a say in what happens in the group, consensual validation, closeness. 
Integration and fulfilment of needs: feeling that members' needs will be met by the resources of the group and through membership, reinforcement, rewarding to members, status of membership, group success, group and individual competence, serve individual's needs by belonging, shared values, members are able and willing to help one another and receive help in return.

Shared emotional connection: the commitment and belief that the community has (and will continue to share) a history, common places, shared events, time together, and similar experiences, positive experiences among group members; relationships and bonds between members; completed tasks; shared importance of tasks/events; investment (time, money, intimacy); emotional risk between members; honours; rewards and humiliation by the community have an impact on members; spiritual bonds.

From the foregoing we can deduce at least two points that cement/bind together a community. Reciprocity and mutual co-existence, existence of oneself for self and other.....sharing, collective ownership. This blends well with the African philosophy of Ubuntu/ Botho (Letseka 2000; Hlalele 2015; Le Grange 2012; Oppenheim 2012). The individual is seen in relation to the collective (Prinsloo 2000; Metz 2007; Beets 2012; Furman 2012). Gunsfield (1975 cited in McMillan and George 1986:6) distinguished between two major uses of the term community. Firstly, the 'territorial' or geographical notion of community-neighourhood, town, city. The second is 'relational', concerned with 'quality of character of human relationships without reference to location. According to Casto and Audley (2008:12) schools that have achieved a positive, strong sense of community generally share a broad range of qualities including:

Staff, learners, and their families feel as if they belong to the school and as if the school belongs to them. All members of the community feel obliged to play a role that will further contribute to a feeling of being part of the school and vice versa. Adults attached to the school feel a shared sense of responsibility for learners' academic, social, physical, and emotional welfare. Learners feel safe and significant wherever they are in the community. There exists agreed upon standards for learner behaviour and learning throughout the 
community. Members of the community coordinate their efforts to help the learners to meet expectations mainly regarding educational attainment. Members of the community interact with one another in a genuinely caring and respectful manner. Relationships within the community are a model for the welcoming, friendly and cooperative behaviour that is expected of the learners.

The University of the Free State Community Engagement Policy (2007:8) regards communities as specific, collective interest groups, conjoined in their search for sustainable solutions to development challenges, that participate or could potentially participate as partners in the similarly inclined community service activities of the UFS, contributing substantially to the mutual search for sustainable solutions to jointly identified challenges and service needs through the utilisation of the full range of resources at their disposal.

\section{Research Design}

\section{Approach}

This primarily exploratory and descriptive study uses a mixed method design to explore teachers' sense of community in rural learning ecologies. According to De Vos, Strydom, Fouchẻ and Delport (2011) exploratory studies are conducted to gain insight into particular situations, phenomena, or communities or individuals. The need for such studies could arise out of a lack of understanding of a new area of interest, or in order to be acquainted with a situation (Fouchẽ 2005). Historically, rurality and rural education have been marginalised bodies of knowledge in South Africa (Nkambule, Balfour, Pillay \& Moletsane 2011). Nkambule et al. (2011) further state that despite several interventions, education in rural areas continues to face a set of challenges due to, among other factors, the diverse geographic location of the schools, diverse learners' backgrounds and diverse learning styles. Therefore, there exists a need to explore the subject at hand. According to Neuman (2011) we use exploratory research when the subject is very new or if we know little or nothing about it. A descriptive study provides a picture of the specific details of a situation, a social setting, a relationship (Neuman 2011) or a picture of a phenomenon as it naturally occurs (Bickmann \& Rog 2011). The descriptive section of this study blends well with its exploratory orientation as it (the study) begins with a well-defined subject/ issue (i.e., teachers' sense of community) 
and sought to illuminate the basic facts on the issue (De Vos et al. 2011; Neuman 2011).

\section{Participants}

For generating quantitative data, participants in the study were 161 teachers serving in rural and farm schools [rural learning ecologies] in the Free State province of South Africa. Whilst the number of participants may be seen to be lower (i.e., 161), we are of the view that the study covered a broader area and a larger number of schools since most schools in rural learning ecologies have lower than ten teachers at any one point, due to the lower number of learners. The results revealed that 72.05 percent of the teachers in the sample were female; 80.75 percent resided in rural learning ecologies; and 83.85 percent of them spoke the local language as their home language. Their average age in years was 43 with a range of 19 years (i.e., between the oldest and the youngest), and they have spent on average, of 11 years in their respective schools.

\section{Reliability and Validity}

Reliability refers to the degree of consistency of the data gathering instrument in measuring that which it is supposed to measure. According to Tavakol and Dennick (2011: 53) Cronbach Alpha was developed by Lee Cronbach in 1951 to provide a measure of the internal consistency of a test or scale; it is expressed as a number between 0 and 1 . Internal consistency describes the extent to which all the items in a test measure the same concept or construct and hence it is connected to the inter-relatedness of the items within the test. The Cronbach Alpha coefficient for this study was 0.71 which is, according to Peters (2014: 57) acceptable. As a caution Tavakol and Dennick (2011: 54) indicate that the maximum alpha value of 0.90 has been recommended since the one greater than 0.90 suggests that some items are redundant as they are testing the same question but in a different guise.

\section{The Questionnaire}

This small-scale quantitative study administered the revised 24-item Sense of Community Index (SCI-2) questionnaire which has four subscales/domains. 
The questionnaire consisted of the initial question and subscales/domains included reinforcement of needs (questions 1 to 6); membership (question 7 to 12 ); influence (question 13 to 18 ) as well as shared emotional connection (question 19 to 24). The questionnaire was adapted to include biographical details (gender, age, number of years served at a particular school as well as the nature of place of residence) (Warner, Kerwin \& Walker 2013; Vanover 2014; Morgan 2015; Mamonov, Koufaris \& Benbunan-Fich 2016; Halamová, Kanovský \& NaniŠtova 2018).

\section{Quantitative Data Analysis}

\section{Interpreting the Initial Question}

The initial question sought to probe how important was it to teachers to feel a sense of community with other community members. On a six-point Likert scale, a mean score of 5.08, median and mode of 5 (for both) surfaced. This means that an overwhelming majority of teachers were of the view that it is important for them to feel a sense of community with other community members in rural learning ecologies.

\section{Table 1: Distribution according to age}

\begin{tabular}{|c|c|c|c|c|}
\hline & Reinforcement & Membership & Influence & Shared \\
\hline Age & 0.09630 & 0.04426 & 0.02049 & 0.00530 \\
\hline
\end{tabular}

Table 1 exhibit the correlation coefficient (r) that measures the strength of the relationship between age and four domains as shown. $r=0.0963$ captures the existence of relationship between age and reinforcement and $r=$ $0.044 ; 0.020 ; 0.0053$ for membership, influence, shared respectively. Based on the positive correlation coefficients $(r)$ less than 0.5 , we construe that there is a weak positive relationship that exists between age and reinforcement, membership, influence as well as shared emotional connections. Therefore, this means that teachers' responses to all four domains are not strongly explained by age patterns. However, one notable fact is that $r$-value for shared emotional connection is too small, this implies that age difference does not seem to capture how community members have a sense of sharing emotional connections. 
Teachers' Sense of Community in Rural Learning Ecologies

Table 2: Correlation Matrix

\begin{tabular}{|l|c|c|c|c|}
\hline & Reinforcement & Membership & Influence & Shared \\
\hline Reinforce-ment & 1 & 0.72418 & 0.60514 & 0.71240 \\
\hline Membership & 0.72418 & 1 & 0.73420 & 0.76923 \\
\hline Influence & 0.60514 & 0.73420 & 1 & 0.75622 \\
\hline $\begin{array}{l}\text { Shared emotion- } \\
\text { al connection }\end{array}$ & 0.71240 & 0.76923 & 0.75622 & 1 \\
\hline
\end{tabular}

Table 2 sketches the correlation structures that exist between all four domains. The main diagonal of the correlation matrix shows that interaction between each variable by itself hence all values equal to 1 . Row one of the matrix shows how reinforcement correlated with other variables. The reinforcement and membership have a very strong positive relationship with the correlation coefficient of 0.72 . Therefore, in the context of this study it means that the way people respond to reinforcement has positive implications to their sense of membership. Furthermore, the correlation matrix shows that there is a relationship between reinforcement and influence, and shared emotions with $\mathrm{r}=0.61 \& \mathrm{r}=0.71$ respectively. This also implies that reinforcement can explain the both influence and shared emotional connection. More so, Membership in row two exhibit $r$ - values that are greater than 0.7 which attest to the existence of a strong positive relationship between membership and all other variables. This implies that membership seem to explain the patterns observed in other domains. This trend is observed in other domain such as influence and shared emotional connection. Furthermore, relationship is statistically significant for all domains since $r$-values $\mathrm{p}=0.001<0.05$.

Table 3: Distribution according to gender

\begin{tabular}{|l|c|c|c|c|}
\hline \multicolumn{1}{|c|}{ Domains } & \multicolumn{2}{c|}{ Gender } & Difference & $\begin{array}{c}\text { P- } \\
\text { values }\end{array}$ \\
\hline & Male mean & Female mean & & \\
\hline Reinforcement & 2.54 & 2.74 & 0.20 & 0.09 \\
\hline Membership & 2.60 & 2.66 & 0.05 & 0.62 \\
\hline Influence & 2.83 & 2.79 & 0.04 & 0.75 \\
\hline $\begin{array}{l}\text { Shared emotional } \\
\text { connection }\end{array}$ & 2.744 & 2.85 & 0.11 & 0.38 \\
\hline
\end{tabular}


Table 3 above shows the participants' mean responses over the all four domains. From mean values exhibited on this table, one can construe that most participants responded positively to the questions since the highest number on the scale is 3 . We observed a minimum average of 2.54 for both male and female which attest to positive response. However, a question of interest is that are the difference in mean responses gender sensitive? We performed t-test, to test if the difference in mean is gender sensitive and results are reported in Table 3 above. According to the t-test results, there is no significant difference in male and female mean responses since all p-values $(0.09 ; 0.62 ; 0.75 ; 0.38)$ over all domains are greater than the 0.05 significance level. This implies that female and male responses in this study were not influenced by gender.

\section{Table 4: Distribution according to Residence}

\begin{tabular}{|l|c|c|c|c|}
\hline \multicolumn{1}{|c|}{ Domains } & \multicolumn{2}{c|}{ Residence } & Difference & $\begin{array}{c}\text { P- } \\
\text { values }\end{array}$ \\
\hline & Urban mean & Rural mean & & \\
\hline Reinforcement & 2.74 & 2.67 & 0.08 & 0.54 \\
\hline Membership & 2.76 & 2.61 & 0.144 & 0.24 \\
\hline Influence & 2.97 & 2.77 & 0.20 & 0.10 \\
\hline $\begin{array}{l}\text { Shared } \\
\text { emotional } \\
\text { connection }\end{array}$ & 2.93 & 2.80 & 0.13 & 0.33 \\
\hline
\end{tabular}

Table 4 above shows the participants' mean responses over the all four domains as according to residence. From mean values in Table 4, we can infer that most participants responded positively to the questions since the highest number on the scale is 3 but we observed a minimum average of 2.61 for both urban and rural. However, there are differences in the mean responses of urban and rural participants. In order to find if the difference in mean is statistically significant we performed a t-test with the null hypothesis that there is no difference in the mean responses of rural and urban. The t-test results show that there is no significant difference in male and female mean responses since all p-values $(0.09 ; 0.62 ; 0.75 ; 0.38)$ over all domains are greater than 0.05 significant level. This implies that urban and rural responses in this study were not influenced by residence as a variable. 


\section{Qualitative Data Analysis}

The qualitative data was generated through a narrative inquiry which is a ubiquitous practice in that human beings have lived out and told stories about that living for as long as we could talk (Clandinin \& Connelly 2000; Clandinin 2006; Chou, Tu \& Huan 2013). These lived and told stories and the talk about the stories are one of the ways that we fill our world with meaning and enlist one another's assistance in building lives and communities. The narrative approach acknowledges human experiences as dynamic entities that are in a constant state of flux (Lemley \& Mitchell 2011; Yin 2014; Wang \& Geale 2015; Wang, Andre \& Greenwood 2015). Teachers were prompted to comment on the importance of a school in rural learning ecologies.

\section{The Importance of a School in Rural Learning Ecologies}

The school serves as fundamental institution in which learners consider a vehicle to better their lives and that of their families. It is perceived as a training ground, from which after completion of grade 12, children would be better equipped for life-long responsibilities.

From the above, it is noted that teachers regard the school as a bedrock/ springboard from which lives unfold and flourish.

\section{A Sustainable Rural School}

It is important for government to support rural schools in the following areas: infrastructure (roads and school buildings) and basic needs such as water, electricity and toilets. Given the conditions of poor roads that lead to rural schools, government need to regularly renovate these roads and provide quality transport for learners living around the farms.

In respect of sustainability, we notice an expectation that help would emerge from outside the community [from government]. This is inconsistent with current thoughts around seeing rurality as beset with assets that may be tapped into (Myende \& Hlalele 2018). Further, a sense of community/ belonging was probed. 


\section{Sense of Community/ Belonging}

The community through SGB's does get involved in the affairs and management of the school. They support in the maintenance, renovation and security of the school. Parents teach their children why they should regard the school as belonging to their community.

The pivotal role played by parents in sensitizing their children to observing the school as owned by the community is noted. The silence from the three written narrative regarding a sense of community pertains to teachers themselves. Whilst quantitative data in this study indicates that teachers have a stronger sense of community towards rural learning ecologies, blind spots/silences in respect of this matter is observed. The study further probed socializing as a facet of sense of community.

\section{Socialising}

Great interaction exist between teachers of farm schools. Teachers, parents and children from the school do attend funerals, weddings, church, join whatsapp and facebook groups and share ideas, great moments and even grief.

The above shows participation in a number of common community activities attended by parents, teachers and learners. Social media is also mentioned as an enabler for interaction between community members. We thought it would be interesting to probe how the teacher is positioned within rural learning ecologies.

\section{A Rural Teacher}

A teacher is seen as a role model, someone to be treated with respect and dealt with. Sometimes it get worse to an extent where a teacher is idolized as a 'god' perfect without fault and infallible.

Over and above being seen as a role model, there is some sense of a teacher as a savior in the rural community. 


\section{Teaching Responsibilities}

Teachers do take full responsibility and a passionate in teaching in farm schools, despite many challenges. Modern technology teaching aids are not accessible, in instances where they are found, they are not sustainable. Teachers still rely on the old chalkboard style teaching. Multi grade classes still prove a challenge. A single teacher is expected to teach many subjects because of the number of children in the school.

Despite a positive feeling about being a teacher in rural learning ecologies, challenges are also noted. The above details some of the shortages. It would have been helpful to probe recognition of some assets that may not necessarily be found elsewhere.

\section{School - Community Partnerships}

School - community partnerships play a major role in enhancing and strengthening a sense of community in rural learning ecologies. Teachers indicated that:

The school boast of great partnership with the community organizations, ranging from government, private sector business to non profit entities. Security and check-ups is conducted by the SAPS in their program of adopting schools to ensure a safe and secure learning environment. Church institutions do offer religious support, spiritual counseling and social assistance e.g. uniforms and clothes to children. Local business provide financial support in programs or events that the school organize.

From the above, it is clear that rural learning ecologies thrive when their diverse partners play a decisive role.

\section{Discussion of findings}

Results of this study indicate that it is important for teachers to feel a sense of community with other community members in rural learning ecologies. In the 
current study, the existence of a strong positive relationship between membership and all other domains surfaced. According to Dueber and Misanchuk (2001: 7),

membership deals not only with who is in or not in a community, but with the sense of safety that accompanies such delineation. The ability to identify another member of a community allows people to better determine how to spend resources and with whom to feel comfortable.

The question of relationships is taken further by Levebre (1999 cited in Blewitt 2006: 14) who states that:

we deal with relationships on a daily basis and every day is where we are in terms of our direct relationship with the social and natural worlds and where our desires, capabilities, identities and potential are, in the first instance, formulated, developed and made real. Everyday life is also the site from which we can fashion a critique of dominant, alienating and exploitive ideas and practices and start to create a new or alternative way of doing things, of thinking and acting, of producing and consuming, combining to develop a new art of living.

Age difference does not seem capture how community members have sense of sharing emotional connections. This finding is inconsistent with the trend that SACE (2011:15) hold as they advance an argument that says:

the younger generation aspires to move out of their rural lifestyles, while those with tertiary qualifications, after a period of urban living, eventually opt to return to their rural homes, out of a sense of responsibility to the family, due to emotional ties with home that the younger generation may not necessarily have.

There is a strong positive relationship between reinforcement and membership. This is consistent with the strong relationship between reinforcement and 
influence. This implies that teachers in rural learning ecologies view themselves as capable of influencing other members of the community and as amenable to being influenced in return. This reciprocity provides for pervasive co-existence as teachers are of the view that their terrain extends beyond the confines of the fences surrounding their respective schools.

There is no significant difference in male and female participants' all the four domains. This implies that responses are not influenced by gender. This is inconsistent with general societal gender dispositions. According to Eckert and McConnell-Ginet (2013: 1),

We are surrounded by gender lore from the time we are very small. It is ever-present in conversation, humour, and conflict, and it is called upon to explain everything from driving styles to food preferences. Gender is embedded so thoroughly in our institutions, our actions, our beliefs, and our desires, that it appears to us to be completely natural. The world swarms with ideas about gender - and these ideas are so commonplace that we take it for granted that they are true, accepting common adage as scientific fact.

The assertion above points to the fact that we remain highly gendered as a society. Males and females are expected to behave differently even if they assume the same responsibilities [of being a teacher in a rural learning ecology]. Findings of this study are encouraging as they indicate a paradigm shift-a shift that holds true the fact that males and females do not necessarily need to behave differently.

There is no difference in the mean responses regarding rural and urban as places of residence for teachers. This implies that rural and urban responses are not influenced by residence. This means that teachers who stay in urban areas evinced the same sense of belonging, membership, shared emotional connection as well as influence as their counterparts who stay in rural learning ecologies. Incentives may have played a significant role in respect of this trend. According to the Adedeji and Olaniyan (2011) and SACE (2011) providing incentives to qualified teachers to remain in the rural learning ecologies and teach is likely to yield positive results for increasing the numbers of teachers in rural schools. Brown (2003) provides a slightly different angle when he states that the 'ideal' rural teacher can teach multiple grades or subjects, organize extracurricular activities, and adjust well to the environment and the 


\section{Dipane Hlalele \& Moeketsi Mosia}

community. In addition, Chigbu (2013: 264) opines that a sense of community in rural ecologies is constituted by 'a rural mind, rural life and rural character'. The assertion by Brown is supported by Hlalele (2014) who states that usually the teachers who end up staying are either from a rural background or have previous experience with rural communities. Such teachers interact with the members in their ecologies on at least two levels. One is that is that of common expectation and one of fulfilment on the other hand. With regard to expectation, the teachers:

get important needs of theirs met because they are part of the community; value the same things as other community members; the community has been successful in getting the needs of its members met; feel good as members; when they have a problem, they can talk about it with members of this community; have similar needs, priorities, and goals; can trust people in their community as well as recognize most of the members of their community.

On the other hand, fulfilment comes across when teachers:

put a lot of time and effort into being part of the community; feel that being a member of the community is a part of their identity; feel that fitting into their community is important to them; feel that their community can influence other communities; care about what other community members think of them; have influence over what their community is like; believe that their communities have good leaders; feel that it is very important to them to be a part of their community; expect to be a part of their community for a long time; and are hopeful about the future of their community.

The discussion above suggests the existence of inviting elements such as sense of belonging, trust, patriotism, as well as we-ness. In such situations, emancipatory and participatory inclinations are likely to imbue such ecologies. Strong internal relationships are more likely, over and above entrenching membership, shared emotional connection, a feeling that the individual is capable of exerting some influence over activities and other members (Farahani 2016; Mahdi 2018), to source valuable external relationships that may benefit the broader learning ecologies resulting in cross-pollination. The 
current study was conducted in rural South Africa. Using the SCI-2, and narratives, the study may appeal to many other parts of the world and areas of study (Warner, Kerwin \& Walker 2013; Morgan 2015; Mamonov, Koufaris \& Benbunan-Fich 2016). According to Halamová, Kanovský and NaniŠtova (2018) sense of community is associated with a significant number of positive consequences for individuals and communities as well as society.

\section{Conclusion}

The study sought to explore teachers' sense of community in rural learning ecologies. Whilst there are many negative perceptions associated with teaching in rural learning ecologies, the current study portrays a paradigm shift where negativity does no longer occupy centre stage. It showed positive inclinations towards rural schools and communities. Despite notable challenges, teachers who 'feel' positive towards their communities may be more likely to engage in healthy, enjoyable and kindling interactions with fellow community members.

Acknowledgement: This work is based on the research supported by the National Research Foundation of South Africa for the Grant, Unique Grant No: 87694 and any opinion, finding and conclusion or recommendation expressed in this material is that of the author(s) and the NRF does not accept any liability in this regard.

\section{References}

Adedeji, S.O. \& O. Olaniyan 2011. Improving the Conditions of Teachers and Teaching in Rural Schools across African Countries. Addis Ababa: UNESCO-IICBA.

Barley, Z.A. 2009. Preparing Teachers for Rural Appointments: Lessons from the Mid-continent. The Rural Educator 30: 10 - 15.

https://doi.org/10.35608/ruraled.v30i3.444

Beets, P.A.D. 2012. Strengthening Morality and Ethics in Educational Assessment through Ubuntu in South Africa. Educational Philosophy and Theory 44,2: 68 - 83.

https://doi.org/10.1111/j.1469-5812.2011.00796.x

Bennell, P. 2004. Teacher Motivation and Incentives in Sub-Saharan Africa 
and Asia. Knowledge and Skills for Development, Brighton.

Bickmann, L. \& D.J. Rog 2009. The SAGE Handbook of Applied Social Research Methods. Thousand Oaks, CA: SAGE.

https://doi.org/10.4135/9781483348858

Blewitt, J. 2006. The Ecology of Learning: Sustainability, Lifelong Learning and Everyday Life. London: Taylor and Francis.

Boyd, N. \& B. Nowell 2017. Testing a Theory of Sense of Community and Community Responsibility in Organizations: An Empirical Assessment of Predictive Capacity on Employee Well-being and Organizational citizenship. Journal of Community Psychology 45,2: 210 - 229.

https://doi.org/10.1002/jcop.21843

Brown, D.C. \& K.A. Schaff 2011. Rural People and Communities in the $21^{\text {st }}$ Century. Cambridge: Polity Press.

Casto, K.L. \& J.R. Audley 2008. A Framework for Building School Wide Community. London: Northeast Foundation for Children.

Centre for Education Policy Development (CEPD) 2011. Teaching Literacy and Numeracy in Multigrade Classes in Rural and Farm Schools in South Africa. Johannesburg: CEPD.

Chigbu, U.E. 2013. Fostering a Rural Sense of Place: The Missing Piece in Uturu, Nigeria. Development in Practice 23,2: 264 - 277.

https://doi.org/10.1080/09614524.2013.772120

Chou, M.J., Y.C. Tu \& K.P. Huang 2013. Confucianism and Character Education: A Chinese View. Journal of Social Sciences 9, 2: 59 - 66. https://doi.org/10.3844/jssp.2013.59.66

Clandinin, J. 2006. Handbook of Narrative Inquiry: Mapping a Methodology. London: Sage.

https://doi.org/10.4135/9781452226552

PMCid:PMC4065867

Clandinin, D.J. \& F. M. Connelly 2000. Narrative Inquiry: Experience and Story in Qualitative research. San Francisco: Jossey Bass.

Cross, C., J. Seager, M. Wentzel, J. Mafukidze, F. Hoosen \& J. Van Zyl 2009. Migration Management Challenges in South Africa: The Next Ten Years. Report presented to Centre for Development and Enterprise. Urban, Rural and Economic Development Programme. Pretoria: Human Sciences Research Council.

De Vos, A.S., H. Strydom, C.B. Fouchẻ \& C.S.L. Delport 2011. Research at Grass Roots: For the Social and Human Sciences. Pretoria: Van Schaik. 
Dueber, B. \& M. Misanchuk 2001. Sense of Community in a Distance Education Course. Paper presented at Mid-South Instructional Technology Conference Murfreesboro, TN, April 8-10, 2001.

Eckert, P. \& S. McConnell-Ginet 2013. Language and Gender. $2^{\text {nd }}$ Edition.

Cambridge: Cambridge University Press.

https://doi.org/10.1017/CBO9781139245883

Farahani, L.M. 2016. The Value of the Sense of Community and Neighbouring. Housing, Theory and Society 33,3: 357 - 376.

https://doi.org/10.1080/14036096.2016.1155480

Ferris, K.A., B. Oosterhoff \& A. Metzger 2013. Organized Activity Involvement among Rural Youth: Gender Differences in Associations between Activity Type and Developmental Outcomes. Journal of Research in Rural Education 28: 1 - 16.

Fremlin, J. 2012. Sense of Community: Across Online and Offline Communities. Saarbrücken, Germany: LAP Lambert Academic Publishing.

Furman, K. 2012. Exploring the Possibility of an Ubuntu-Based Political Philosophy. Masters Dissertation. Stellenbosch University: Stellenbosch. Halamová, J., M. Kanovský \& E. NaniŠtova 2018. Development and Psychometric Analysis of the Sense of Community Descriptors Scale. Psychosocial Intervention 27,1: 44 - 55.

https://doi.org/10.5093/pi2018a8

Hlalele, D. 2012. Social Justice and Rural Education in South Africa. Perspectives in Education 30: 111 - 118.

Hlalele, D. 2014. Creating Sustainable Rural Learning Ecologies in South Africa: Realities, Lessons and Prospects. Journal of Human Ecology 45: 101 - 110. https://doi.org/10.1080/09709274.2014.11906683

Hlalele, D. 2015. Ubuntu, Adaptive Leadership and Sustainable Futures. Proceedings of the second international dialogue Relational Leadership and Learning for Hope-full and Sustainable Futures, 8 - 10 July 2015, Flinders University, Adelaide, Australia.

Hlalele, D., D. Manicom, J. Preece \& C.T. Tsotetsi 2015. Strategies and Outcomes of Involving Students in Community Engagement: An Adaptive Leadership Perspective. Journal of Higher Education in Africa 13: 169 - 174.

Hlalele, D. \& C. Tsotetsi 2015. Engaging the Community in Educational and Social Amelioration: Lessons and Prospects. Alternation Special Edition 16: $141-165$. 
Hlalele, D. \& C.T. Tsotetsi 2016. Promoting Student Teachers' Adaptive Capabilities through Community Engagement. Perspectives in Education 34,3: 29 - 42. https://doi.org/10.18820/2519593X/pie.v34i3.3

Hopkins, C.D., M.A. Raymond \& L. Carlson 2011. Educating Students to Give Them a Sustainable Competitive Advantage. Journal of Marketing Education 33: 337 - 347.

https://doi.org/10.1177/0273475311420241

Kline, J., S. White \& G. Lock 2013. The Rural Practicum: Preparing a Quality

Teacher Workforce for Rural and Regional Australia. Journal of Research in Rural Education 28: 1 - 13.

Le Grange, L. 2012. Ubuntu, Ukama and the Healing of Nature, Self and Society. Educational Philosophy and Theory 44: 56 - 68.

https://doi.org/10.1111/j.1469-5812.2011.00795.x

Lemley, C.K. \& R.W. Mitchell 2011. Narrative Inquiry: Stories Lived, Stories

Told. Chichester: Wiley.

Letseka, M. 2000. African Philosophy and Educational Discourse. In Higgs, P.

N.C.G. Vakalisa, T.V. Mda \& N.T. Assie-Lumumba (eds.): African

Voices in Education. Juta: Lansdowne.

Mahdi, T.C. 2018. Membership vs. Being of the Community: A Qualitative Study of the Go-Go Music - Cultural Community. Doctoral Thesis. Baltimore: University of Maryland.

Mamonov, S., M. Koufaris \& R. Benbunan-Fich 2016. The Role of Sense of Community in the Sustainability of Social Network Sites. International Journal of Electronic Commerce 20,4: 470 - 498.

https://doi.org/10.1080/10864415.2016.1171974

McMillan, D.W. \& D.M. George 1986. Sense of Community: A Definition and Theory. Journal of Community Psychology 3: 4 - 23. https://doi.org/10.1002/1520-6629(198601)14:1<6::AID-

JCOP2290140103>3.0.CO;2-I

Morgan, L.J. 2015. Sense of Community in Doctoral Nursing Programs: A Phenomenological Study. Doctoral Thesis. Atlanta: Mercer University.

Mothowamodimo, W.O. 2011. Re/claiming the River's Edge. Unpublished Doctoral Thesis. University of Pretoria: Pretoria.

Mulkeen, A. 2005. Teachers for Rural Schools: A Challenge for Africa. Report on Ministerial Seminar on Education for Rural People in Africa: Policy Lessons, Options and Priorities. Hosted by the Government of Ethiopia, Addis Ababa, 7-9 September, 2005. 
Myende, P. \& D. Hlalele 2018. Framing Sustainable Rural Learning Ecologies: A Case for Strength-based Approaches. Africa Education Review 1-17. https://doi.org/10.1080/18146627.2016.1224598

Neuman, W.L. 2011. Social Research Methods: Qualitative and Quantitative Approaches. Boston: Allyn \& Bacon.

Nkambule, T., R.J. Balfour, G. Pillay\& R. Moletsane 2011. Rurality and Rural

Education: Discourses Underpinning Rurality and Rural Education Research in South African Postgraduate Education Research 1994 - 2004.

South African Journal of Higher Education 25: 341 - 357.

Oppenheim, C.A. 2012. Nelson Mandela and the Power of Ubuntu. Religions 3: 369 - 388. https://doi.org/10.3390/rel3020369

Peters, G.J.Y. 2014. The Alpha and the Omega of Scale Reliability and

Validity: Why and How to Abandon Cronbach's Alpha and the Route

Towards more Comprehensive Assessment of Scale Quality. European

Health Psychologist 16,2: 56 - 69.

Phakathi, P. 2013. New Teachers may be Sent to Rural Areas.

www.bdlive.co/za/national /education/2013/05/29

(Accessed on October 30, 2018).

Prinsloo, A.D. 2000. The African View of Participatory Business

Management. Journal of Business Ethics 25: 275 - 286.

https://doi.org/10.1023/A:1006357127960

South African Council for Educators (SACE) 2011. Teacher Migration in

South Africa: Advice to the Ministries of Basic and Higher Training.

Centurion: SACE.

Tavakol, M. \& R. Dennick 2011. Making Sense of Cronbach's Alpha.

International Journal of Medical Education 2: 53 - 55.

https://doi.org/10.5116/ijme.4dfb.8dfd

PMid:28029643

PMCid:PMC4205511

University of the Free State 2007. Community Engagement Policy. Available at: $\underline{w w w . u f s . a c} . z a$

Vanover, A.C. 2014. The Impact of Sense of Community on Business Unit Work Performance. Honors Program Theses. Paper 14. Rollins College Online.

Wang, C.C. 2017. Chinese Nursing Students at Australian Universities: A Narrative Inquiry into their Motivation, Learning Experience, and Future Career Planning'. PhD Thesis. Edith Cowan University. 
Wang, C.C., K. Andre \& K.M. Greenwood 2015. Chinese Students Studying at Australian Universities with Specific Reference to Nursing Students: A Narrative Literature Review. Nurse Education Today 35, 4: $195-208$.

https://doi.org/10.1016/j.nedt.2014.12.005

PMid:25537169

Wang, C.C. \& S.K., Geale 2015. The Power of Story: Narrative Inquiry as a Methodology in Nursing Research. International Journal of Nursing Sciences 2, 2: 195 - 198.

https://doi.org/10.1016/j.ijnss.2015.04.014

Warner, S., S. Kerwin \& M. Walker. 2013. Examining Sense of Community in Sport: Developing the Multidimensional 'SCS' Scale. Journal of Sport Management 27,5: 349 - 362.

https://doi.org/10.1123/jsm.27.5.349

Wentzel, M. \& K. Tlabela 2006. Historical Background to South African migration. In Kok, P., D. Gelderblom, J. Oucho \& J. Van Zyl (eds.): Migration in South and Southern Africa: Dynamics and Determinants. Cape Town: HSRC Press.

White, S. 2010. Creating and Celebrating Place and Partnerships: A Key to Sustaining Rural Education Communities. Paper presented at the Society for the Provision of Education in Rural Australia conference, Sippy Downs, Queensland, September 2010.

Dipane Hlalele Educational Psychology School of Education Edgewood Campus University of Kwazulu-Natal hlaleled@ukzn.ac.za

Moeketsi Mosia Centre for Teaching, Learning and Programme Development Sol Plaatje University moeketsi.mosia@spu.ac.za 